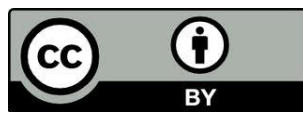

\title{
VIVENDO TRIUNFANTEMENTE - OS CAMINHOS PARA A VITÓRIA E O BEM-ESTAR EMOCIONAL NA COMUNICAÇÃO DE SILAS MALAFAIA (2000-2010)1
}

Living triumphantly - The paths to victory and emotional well-being in communication Malafaia Silas (2000-2010)

Karina Kosicki Bellotti Professora do Departamento de História da Universidade Federal do Paraná, com pesquisas na área de Religião, Mídia e Cultura.

(DVD Vivendo triunfantemente, Silas Malafaia, c.2000s).

RESUMO: O tema deste artigo é o ministério de comunicação do pastor assembleiano Silas Malafaia para apresentar reflexões sobre a cultura do bem-estar difundida nos meios evangélicos brasileiros nos últimos dez anos. Nosso foco justifica-se por conta de seu sucesso de vendas em rankings publicados na Revista Consumidor Cristão (EBF Editora), desde 2002 e por ser um dos pastores de atuação mais longeva nos meios de comunicação evangélicos. Ele tem se tornado também conhecido por seu ativismo político nas eleições de 2010 (presidência) e 2012 (municipais), dentro e fora dos meios evangélicos. Contudo, nós nos centraremos nos materiais produzidos por este pastor no que se refere à promoção do bem-estar físico, emocional e material, que toma uma grande dimensão de seu ministério.

Palavras-chave: Protestantismo; Comunicação; Silas Malafaia

ABSTRACT: The subject of this article is the communication ministry of Pastor Silas assembleiano Malafaia to present reflections on the culture of welfare widespread among Evangelicals Brazilians in the last ten years. Our focus is justified because of its sales success in rankings published in the Journal Consumer Christian (EBF Publisher) since 2002 and as one of the most long-lived acting pastors in evangelical media. $\mathrm{He}$ has become well known for his political activism in the 2010 elections (presidential) and 2012 (municipal) inside and outside the evangelical media. However, we will focus on the materials produced by this pastor with regard to the promotion of physical wellbeing, emotional and material, which takes a large dimension of his ministry.

Keywords: Protestantism; Communication; Silas Malafaia

\footnotetext{
${ }^{1}$ Parte das conclusões deste estudo foram apresentadas no III Encontro do GT História das Religiões e Religiosidades da Anpuh em 2010. Esse estudo faz parte de projeto de pós-doutorado financiado pela Fapesp, "Desfrutando a vida diária: a cultura do bem-estar na mídia evangélica no Brasil (1950-2000)", em que analisei a produção de Joyce Meyer, Max Lucado, Augusto Cury e Silas Malafaia, e sua circulação pelo mercado evangélico e redes sociais.
} 
"Você é mais do que vencedor, é vitorioso" "Vencer na vida não é tão somente um sonho - ontem e hoje, tem sido uma realidade na vida de muitos que confiam no Senhor" (Malafaia, 2009, p. 8)

"Se você quer viver triunfantemente, a primeira coisa a fazer é praticar a Palavra de Deus. Você não poderá viver triunfantemente no sentido completo da palavra se não amar e praticar a Lei do Senhor. Tenha prazer na Lei do Senhor e esteja previamente preparado contra os conselhos dos ímpios (Salmo

O bem-estar é um poderoso carro-chefe da sua propaganda de um estilo de vida cristão, pois valeria a pena ser evangélico para se conquistar o bem-estar emocional. Nesse estilo de vida cristão, encontramos algumas diferenciações perante a vida no "mundo", visto que determinadas características são valorizadas nessa literatura e nos produtos encontrados no mercado evangélico: ética, modéstia, mordomia, prosperidade, parcimônia, alegria; a diferenciação perante realidade brasileira do "jeitinho", da corrupção; diferenciação dentro do campo religioso brasileiro, por meio de uma identidade que promete paz de espírito dentro de princípios práticos, simples e fáceis de localizar dentro da Bíblia, pelo intermédio de líderes e pregadores carismáticos.

Tanto nos Estados Unidos desde os anos 1940, quanto no Brasil desde os anos 1980, escritores evangélicos divulgam mensagens de conforto espiritual e de incentivo ao bem-estar individual para um grande público, tratando de temas genéricos que tendem a afetar cada vez mais pessoas: ansiedade, depressão, stress, nervosismo, pressão cotidiana, sensação de insegurança. E, ao mesmo tempo, eles estabelecem sua marca pessoal, que tornaria a produção deste ou daquele produtor de mídia mais "verdadeira" e "autêntica" do que a os demais - por exemplo, Malafaia é o pastor da vitória e da prosperidade, assim como Joyce Meyer é a pregadora de cura emocional (Bellotti, 2011) e Max Lucado, o pastor que prega viver "o hoje", aliviando a bagagem da jornada (Bellotti, 2012). Cada qual traz em suas mensagens suas marcas pessoais, que se tornam parte do produto, do seu "diferencial" de consumo. Mas também dialogam com ideias que circulam há muitos anos nas prateleiras do supermercado cultural brasileiro e norte-americano, e que reaparecem a cada ano sob diferentes 
rótulos: auto-ajuda/ auto-ajuda cristã; vida cristã; inspiracional; edificação.

As matrizes culturais e teológicas que deram origem a estas mensagens encontram-se nas correntes do Novo Pensamento, do Pentecostalismo de Cura Divina, do Gospel of Health and Wealth e da Confissão Positiva, em especial em suas relações com a cultura norte-americana dos anos 1950 e 1960. Parte dessa produção chegou ao Brasil a partir dos anos 1960, estabelecendo relações entre o corpo, a mente e o conceito de felicidade e realização pessoal, dentro de um contexto de surgimento de ideais de felicidade aliada ao consumo, à propaganda e à "suburbanização" da sociedade americana.

A expansão dessa literatura seguiu-se no esteio da expansão pentecostal a partir dos anos 1950 e 1960 no Brasil, aliada a uma estratégia de investimento em meios de comunicação de massa, ao mesmo tempo em que, desde os anos 1950, títulos de Dale Carnegie ("Como fazer amigos e influenciar pessoas) e Norman Vicent Peale ("O poder do pensamento positivo") encontravam-se traduzidos para o português.

Contudo, a maior quantidade de títulos lançados sob o termo "auto-ajuda" cristã encontra-se nos anos 1990 e 2000, período de maior crescimento na porcentagem de evangélicos no Brasil, e em sua grande maioria são obras de norte-americanos. Segundo a psicóloga Daniela Bessa, muitas dessas obras possuem em comum determinadas ideias, tais como:

“o universo é um lugar justo e organizado em que tudo visa ao bem-estar do ser humano, o ser humano deve se submeter ao amor de Deus, sem o qual sua vida fica incompreensível e necessita de redenção. Deus é um pai amoroso e confiável, e o mal tem origem satânica". Defendem ainda que o amor a si mesmo é imperativo para o amor ao próximo. Cura interior e batalha espiritual são aliadas nessa literatura, em que "tanto as necessidades do presente, quanto as do futuro são atendidas, Bíblia e Psicologia são colocadas como auxílios complementares, a vontade humana e a soberania divina parecem caminhar juntas" (Bessa, 2008, pp. 118-119;121).

A presença de elementos psicológicos nas obras de auto-ajuda, a fim de ajudarem os fiéis a aproveitarem melhor a vida em diversos aspectos, é uma constante nessa produção, sendo importante para analisar a cultura do bem-estar. Assim, entende- 
se que seus produtos oferecem uma direção, ainda que temporária, para indivíduos que se sentem vulneráveis, dentro de um contexto de reflexibilidade, no qual os indivíduos empreendem uma constante e incessante reconstrução do $e u$ mediante a consulta ao discurso midiático dos especialistas em auto-ajuda e religião.

Nosso enfoque teórico-metodológico desenvolvido neste trabalho contempla as diferentes funções que a comunicação tem adquirido no universo evangélico brasileiro: espelho para comportamentos exemplares, dentro de uma ideia mais ampla de reflexividade (Giddens, 1991), evangelização para não-iniciados ou não-convertidos, instrução e edificação para os convertidos, legitimação e autoridade para determinados líderes e pregadores. Sob o prisma de uma História Cultural das religiões, a comunicação pode ser considerada como uma prática a ser reapropriada no cotidiano, em diferentes graus de relação com o que os guardiães da religião instituída pregam. A análise das mensagens contidas nos produtos deve prever suas possíveis aberturas para as recepções e consumos do público-alvo, ainda que não tenhamos contemplado nessa parte da pesquisa as recepções - nesse tipo de comunicação, interessa-nos entender a forma como os produtores da mensagem constroem seu público-alvo, identificando seus problemas e oferecendo soluções. Isso implica analisar a autoimagem construída pelo pregador, e análise da mensagem e dos formatos dos produtos mais significativos com as mensagens sobre bem-estar emocional.

\section{Construindo a imagem pública pelo Ministério de Comunicação}

Silas Malafaia (1958-) é pastor da Assembléia de Deus Vitória em Cristo,com sede no Rio de Janeiro-RJ, sendo comumente apresentado em seus diversos produtos de mídia como "psicólogo, conferencista internacional, professor de Teologia", além de vice-presidente do CIMEB (Conselho Interdenominacional de Ministros Evangélicos do Brasil). O seu grande setor de atuação desde 1982 tem sido a televisão, com o programa "Vitória em Cristo" (primeiramente denominado "Renascer" e "Impacto"). Desta atuação surgem outros produtos com a marca "Silas Malafaia": mensagens televisionadas transformadas em VHS e DVD, livros (em geral, transcrições mais simplificadas das mensagens de TV e de conferências gravadas), e CDs de pregações, 
todos comercializados pela sua editora, Central Gospel, com sede do Rio de Janeiro ${ }^{2}$.

Sua pregação emocionada, muitas vezes coloquial, despojada, com estilo brincalhão, apaixonado e arrivista, tem como alvo preferencial a comunidade de cristãos convertidos, sem deixar de fora potenciais cristãos e cristãos que se afastaram de suas igrejas. Uma de suas mensagens centrais encontrada nos materiais analisados tem sido a ideia de que todo cristão é fadado à vitória sobre seus problemas, com a ajuda de Cristo. Desta forma, a concepção de bem-estar na obra deste comunicador está intimamente ligada à ideia de "vitória em Cristo", que se alcança pela parceria entre o ser humano e Deus em todos os setores da vida humana. Sua mensagem triunfalista está profundamente ligada a uma ferrenha crítica aos ideais de vida cristã e de vida secular, em que prevaleceriam o egoísmo, o individualismo, o consumismo e a cobiça. Outro pecado muito alvejado pelo pastor na última década tem sido a homossexualidade, porém, se comparada a outros erros apontados por ele, ocupa um espaço reduzido dentro de boa parte do material à venda nos últimos anos ${ }^{3}$.

Em suas pregações, é comum ouvir de Malafaia "receitas de Deus" para o sucesso e para a vitória sobre diferentes tipos de situação: depressão, tribulações, desafios, conflitos. Mas para se atingir essa vitória com a ajuda divina, é necessário que o ser humano se entregue de fato a Cristo, e renuncie às tentações do mundo e aos modismos da igreja - em especial da igreja pentecostal, como por exemplo, ênfase excessiva em anjos, profecias e visões. Pesadas críticas são desfiadas em livros e programas de TV contra práticas dentro das igrejas evangélicas - da teologia da prosperidade a uma excessiva espiritualização de problemas físicos e emocionais. Em

\footnotetext{
${ }^{2}$ Em 15 de maio de 2010, Malafaia anunciou em seu programa de TV a sua saída da Convenção Geral das Assembléias de Deus no Brasil (CGADB), e a mudança do nome da igreja que preside, de Assembléia de Deus da Penha (RJ) para AD Vitória em Cristo, o que demonstraria para muitos evangélicos uma independência ainda maior para a o ministério do pastor. Desde 2010 o programa Vitória em Cristo vem sido dublado em inglês e transmitido pela emissora americana Inspiration para 127 países (segundo site da AVEC - http://www.vitoriaemcristo.org/_gutenweb/_site/hotsite/avec30anos/linha.cfm. Acesso em 27/11/2012).

${ }^{3}$ Ações como a passeata contra a aprovação do Projeto de Lei 122/06 (criminalizando a homofobia), liderada por ele rumo a Brasília em junho de 2006, assim como sua atuação na campanha eleitoral presidencial de 2010, pronunciando-se contra o aborto e à união civil de casais do mesmo sexo, atacando a candidata do PT, Dilma Roussef, e apoiando o candidato do PSDB, José Serra. Em 2012, posicionou-se contra o candidato do PT è prefeitura de São Paulo, Fernando Haddad, por conta de suas medidas antihomofóbicas no Ministério da Educação da gestão Lula e Dilma. Nos últimos cinco anos há cada vez mais notícias da atuação política de Malafaia, com presenças no congresso nacional e com apoios a candidatos a prefeito e vereador - em 2012, nas eleições municipais, apoiou Eduardo Paes (prefeito reeleito do Rio de Janeiro), José Fortunati (prefeito eleito de Porto Alegre), e Marcelo Lellis (candidato aprefeito de Palmas-TO) e Ratinho Jr. (candidato a prefeito de Curitiba).
} 
suas pregações é exortado um modelo de identidade cristã que deve saber viver no mundo conforme princípios cristãos, buscando sempre a santificação, o conhecimento contínuo da Bíblia e a ascensão social por meios honestos - educação, genuína vontade de servir ao próximo e a Deus, ambição para ser uma pessoa e um profissional cada vez mais aperfeiçoado.

Malafaia tem frequentemente referido-se à "lei da liberalidade", que promoveria autêntica prosperidade ao fiel se praticada conforme princípios bíblicos. Se, em meados dos anos 1990, Malafaia recorreu em defesa de Edir Macedo, acusando a grande mídia secular de perseguição religiosa, nos anos 2000 Malafaia critica a Teologia da Prosperidade, instituindo sua própria via de alcançar prosperidade material e espiritual. A fim de construir um espaço de legitimidade na comunicação evangélica, Malafaia adota duas estratégias: reforça sua imagem de vencedor e de pregador carismático, e ao mesmo tempo, desqualifica concorrentes - outros pregadores evangélicos (ainda que nunca cite seus nomes), e a mídia secular como um todo (televisão e internet em especial). Para ele, a mídia é um veículo neutro que tem sido usado para desvirtuar a audiência, altamente suscetível a boatos, a "besteirol" (como ele costuma se referir) e a calúnias contra "homens de Deus" como ele.

Para realizar esta pesquisa foram selecionados treze mensagens em vídeo gravadas em DVD e televisão (com duração de cerca de 50 a 80 minutos cada); e quatro livros, dentro de um universo de 50 programas gravados na televisão em 2008. Desde setembro de 2008, Malafaia alugou as madrugadas da Rede Band de Televisão para divulgar suas mensagens e os produtos da Editora Central Gospel, até 2011. Por isso, além de mensagens em DVD (dos quais selecionamos três), gravamos no período de fevereiro a maio de 2009 o programa "Vitória em Cristo", reprisado duas vezes durante as madrugadas - das $02 \mathrm{~h} 00$ às $03 \mathrm{~h} 00$ (aproximadamente, dependendo da programação da emissora) e das 05h00 às 06h00, além do horário mais conhecido do programa, das $12 \mathrm{~h} 00$ às $13 \mathrm{~h} 00$ aos sábados ${ }^{4}$. Desta amostragem, selecionamos as mensagens que mais se referem ao tema do bem-estar emocional e material do público-alvo. Observamos uma grande repetição de temas e técnicas ("receitas de Deus") para o bem viver do ser

\footnotetext{
${ }^{4}$ É importante acrescentar que com o advento do You Tube, há uma profusão de vídeos do pastor disponíveis, compreendendo pregações completas em diversos eventos e participações em outros programas de televisão. Quem desejar ampliar esta pesquisa possuirá certamente um vasto material para consultar.
} 
humano, ligados à ideia de "vitória em Cristo".

Vale notar a mudança de imagem que Malafaia efetuou após o aluguel do horário da Band (ver figuras 1 e 2): ele raspou o bigode e renovou toda a imagem de todos os produtos em que estampava sua foto. Capas de DVDs de mensagens antigas foram substituídas, e em nenhum programa de TV a sua antiga imagem é vista. A imagem física pode ter mudado, talvez para lhe tirar uma certa sisudez, mas o estilo de pregação continua.
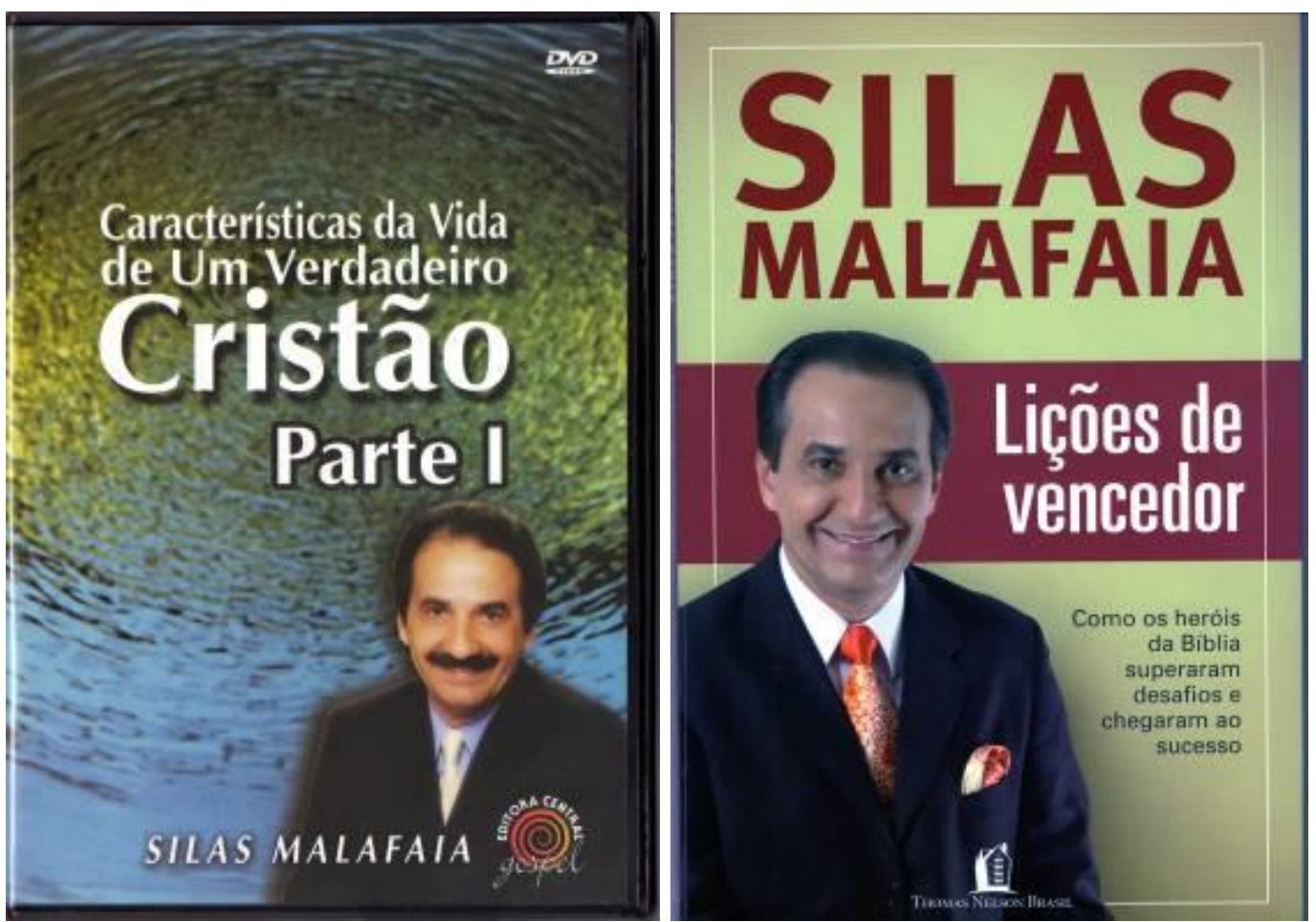

Figuras 1 e 2 - da esquerda para a direita) Malafaia em duas imagens distintas - a primeira figura é da capa do DVD "As características do verdadeiro cristão - Parte 1", sem data discriminada, mas provavelmente de meados dos anos 2000 (ao menos na televisão essa mensagem foi transmitida várias vezes na emissora CNT, Rede TV! e Band em meados dos anos 2000). A mesma imagem ilustrou outras produções de Malafaia em DVD e livros. Após o aluguel de horários da madrugada da TV Band em setembro de 2008, Malafaia adotou uma imagem mais "clean" e rejuvenecida, como pode ser visto na capa do seu primeiro (e até agora único) livro pela Thomas Nelson Brasil, "Lições de Vencedor" (2009).

O ministério de Malafaia completou 30 anos em maio de 2012. Ainda que trabalhe com diversos tipos de produtos, o maior foco do ministério de Malafaia é o uso da televisão. Boa parte dos 45 a 50 minutos do programa "Vitória em Cristo" são ocupados com pregações filmadas em diversas ocasiões e localidades; seja nos congressos e conferências que realiza anualmente, como o "Fogo para o Brasil". Tais mensagens são comercializadas em DVD (anteriormente estavam todas disponíveis em VHS). Em novembro de 2012, o catálogo da Editora Central Gospel contava com cerca 
de 119 produtos de Silas Malafaia, sendo 65 mensagens em DVD e 44 livros. Nenhuma das mensagens traz referência de datas em que as pregações foram gravadas. Por conta da referência a alguns congressos pentecostais em que algumas mensagens foram apresentadas, as mensagens analisadas na amostragem são provavelmente de meados dos anos 2000, tais como os livros.

Além da pregação, Malafaia divulga em seu programa os produtos da Editora Central Gospel (cujo lema é "Impactando vidas e conquistando vitórias"5), além de anunciar eventos nos quais participará - cruzadas, conferências, congressos, e até caravanas para Israel e Egito. No cenário do programa predominam os tons pastéis, composto por um escritório e por um espaço de meditação com uma fonte, em meio a colunas gregas brancas. No escritório, Malafaia aparece sentado a uma mesa de vidro, com alguns livros; e ao fundo, uma grande estante cheia de livros e pequenos objetos de decoração. No espaço aberto, onde ele realiza as orações finais do programa, em primeiro plano está uma fonte, e ao fundo, estão retratados montes. Sempre trajado de terno e gravata, a imagem reforçada nas transmissões é a do pastor que possui uma autoridade sobre o que prega.

O programa é produzido pela Associação Vitória em Cristo de forma independente, sem interferência da emissora Band na sua composição. Ele também é transmitido via internet pelo site oficial do programa, que disponibiliza os programas mais recentes. Até meados de 2009, era possível assistir a diversos outros programas, mas posteriormente foram retirados do site, que hoje podem ser vistos eventualmente no site You Tube. O pastor tem disponibilizado suas mensagens nos mais variados formatos em diferentes canais - até mensagens via celular foram disponibilizadas durante o final de 2008, num esforço caracterizado pela convergência da comunicação (Jenkins, 2008). Além do aluguel do horário da Band, o seu programa tem sido transmitido por diversos outros canais, mediante aluguel de horário ${ }^{6}$. Essa prática o leva a pedir em todos os seus programas doações em dinheiro para manter o programa no ar,

\footnotetext{
${ }^{5}$ Criada em 1999, a Editora Central Gospel serviu para financiar e manter o programa Vitória em Cristo no ar, segundo o próprio site da AVEC (http://www.vitoriaemcristo.org/_gutenweb/_site/hotsite/avec30anos/linha.cfm). Acesso em 27/11/2012.

${ }^{6}$ Por exemplo: TV Porto Visão (Rio Grande do Sul); TV Barriga Verde (Santa Catarina), TV União Acre, entre outras. São ao todo horários alugados em 17 redes regionais, além das transmissões em rede nacional pela Band, CNT, Rede Super, Rede Boas Novas e Rede TV! (dados atualizados em 27 de novembro de 2012). Além disso, desde 2010, o programa tem sido veiculado em inglês, Victory in Christ, pela Daystar e pela Inspiration, para EUA e Canadá.
} 
o que lhe rende muitas críticas de evangélicos e não evangélicos - todas elas rebatidas constantemente em seus programas.

Semanalmente, Malafaia costumeiramente dirige-se ao público acerca de temas recentes ou de fatos pertinentes ao seu ministério, após a transmissão de suas pregações. Por exemplo, quando da sua mobilização contra o Projeto de Lei 122/2006 contra a homofobia, o pastor usa o seu programa para dar recados a opositores e críticos, e responder a boatos, como o fato de ele ser maçom. Ou, mais recentemente, quanto aos posicionamentos políticos que têm demonstrado nas eleições de 2012, em que manifestou apoio a determinados candidatos contrários ao aborto e à união civil de pessoas do mesmo sexo.

Com isso, ele constrói sua imagem de comunicador dinâmico, franco e polêmico, assumindo a autoridade do evangelho e do Espírito Santo, como é de se esperar de um pastor pentecostal. Porém, não faz propaganda de sua igreja, convidando as pessoas a frequentar a Assembléia de Deus Vitória em Cristo, mas sim de seu ministério de comunicação. Em vários momentos, no programa e nos DVDs, ele defende a independência de sua produção, rebatendo críticas feitas aos seus pedidos de doação de dinheiro para manter seu ministério.

A lei da liberalidade, uma forma de alcançar a prosperidade plena, segundo o pastor, é retratada como uma das chaves para a vitória de Malafaia em seu livro "Lições de Vencedor" (Thomas Nelson, 2009). Nessa obra, o pastor mostra como é possível qualquer pessoa alcançar vitória sobre seus problemas com a ajuda "do braço forte do Senhor" (Malafaia, 2009, p.8). Analisa diversas passagens bíblicas em que personagens como Neemias, Elias, Davi e Paulo conseguem triunfar sobre adversidades através da dependência em relação a Deus. No último capítulo, Malafaia discorre sobre as vitórias que Deus teria lhe permitido alcançar em seu ministério. Ainda que em muitos vídeos Malafaia afirme que não está livre de falhas - teria "quebrado" financeiramente seis vezes, por exemplo - ele se retrata como alguém que batalha pelos seus sonhos e objetivos, e possuiria, portanto, autoridade para pregar essa mensagem.

Neste livro, Malafaia afirma que, vindo de uma família evangélica, filho de um pastor da Assembléia de Deus, desde adolescente teve o desejo de ser um pastor que "fizesse a diferença”. Para ele, se Deus plantou um sonho no coração de alguém, ele dará condições para que ele se realize, ainda que seja difícil: "Quem sonha chega a 
algum lugar; pode não chegar ao lugar sonhado, mas algum lugar vai chegar. Essa é a vantagem de sonhar, de projetar e visualizar em nossa mente aquilo que desejamos para a construção da história da vida" (Malafaia, 2009, p. 146). No livro, relata as dificuldades que teve para manter o programa no ar - desde a resistência interna da Assembléia de Deus, até a manutenção financeira do aluguel dos horários. Mas o fato de praticar a lei da liberalidade sempre teria jogado a seu favor:

"Para que o dinheiro não se transforme em nosso deus, temos de praticar um princípio que está na Bíblia: a liberalidade. Ela é uma demonstração real e concreta de que o dinheiro não é o mais importante para você (...) Minha vida tem sido um milagre constante. O programa de televisão, a equipe e as demais coisas que tenho hoje, tudo isso me dá a certeza de que estou colhendo o que plantei. Entretanto, durante 14 anos pratiquei a liberalidade, e nunca vi acontecer nada. Eu ofertava, dava o dízimo, era fiel; cheguei a pegar dinheiro emprestado no banco para ofertar à igreja e a doar um carro como oferta, mas sempre vivia no aperto. De uma hora para outra, contudo, o Senhor começou a abrir portas para mim" (Malafaia, 2009, pp.148-149).

Malafaia procura construir para si a imagem de uma pessoa batalhadora, que aprende na Bíblia a compreender as leis de Deus e que tem moldado seu caráter conforme esses ensinamentos. Com isso, busca delimitar uma legitimidade para seu ministério, mostrando como a comunicação é importante para a obra de Deus, merecedora de investimentos voluntários por parte de fiéis. E até de não evangélicos no vídeo "Uma vida de prosperidade", ele afirma que possuía cerca de 400 colaboradores fiéis não evangélicos. Ainda que ele não faça uma correspondência direta entre a lei da liberalidade e a doação para o seu ministério, ele reforça a importância de se investir em obras que contribuam para a igreja de Cristo no seu amplo sentido. Dentre elas, quem sabe, o seu próprio ministério.

Como parte do esforço de legitimar sua presença na comunicação. Malafaia também recorre à desqualificação de determinados concorrentes. No livro “Atenção!!! Você e sua família estão em perigo" (2004), Malafaia alerta sobre a influência dos programas nocivos da televisão sobre as crianças, os adolescentes e a família. Seu interlocutor é preferencialmente o chefe de família evangélico, dentro de um contexto de família nuclear, tendo como pressuposto que toda recepção aos meios de comunicação é passiva, suscetível a um poder irresistível da TV. Visão semelhante aparece em “O perigo da inversão de valores” (2007), em que ele ataca veementemente 
a internet como veículo de disseminação de boatos e calúnias contra evangélicos. Dentre os efeitos maléficos da televisão estão o imobilismo, o bloqueio da capacidade mental, alienação, mensagens subliminares, dificuldades idiomáticos e consumismo (Malafaia, 2004, pp. 25-29).

Neste livro, ele afirma que "o roteiro e a montagem de filmes, telenovelas $e$ outros programas de TV são, em sua grande maioria, elaborados por pessoas depravadas, anarquistas e homossexuais, que não têm nenhum compromisso com Deus" (Malafaia, 2004, p. 51). Outro alvo são programas evangélicos com doutrinas "antibíblicas" ensinadas por "pregadores eletrônicos": "nesses programas, o telespectador aprende a orar, afastando todo tipo de dificuldade da vida, como por exemplo: 'Eu não aceito ser pobre, não aceito andar a pé, não aceito morar de aluguel'” (Malafaia, 2004, p. 50). Sem citar nomes, não há como não pensar nos programas da Igreja Universal do Reino de Deus e da Igreja Internacional da Graça, que trabalham diretamente com a Teologia da Prosperidade.

No programa Vitória em Cristo de 09 de abril de 2009, com a pregação "Vencendo Batalhas", Malafaia denuncia que na era da informática o ser humano virou $\mathrm{m}$ robô, que acreditaria em tudo o que via e ouvia. O antídoto contra isso era "duvidar, criticar e determinar" todo tipo de informação que recebesse da mídia:

"Eu mesmo e minha família temos sido alvos constantes de mensagens difamatórias publicadas pela Internet. Há algum tempo inseriram um texto dizendo que eu tinha me separado de minha esposa, Elizete (...) Agradeço ao Senhor porque tem mantido no ar um programa evangélico através do qual posso rebater estas calúnias, porém oro para que Ele console e fortaleça os pastores que não têm esta mesma oportunidade de, como eu, poder contar com a mídia para se defender" (Malafaia, 2006, p. 130; 132).

Malafaia considera que seu ministério é um instrumento poderoso de evangelização - de levar o evangelho para quem não o conhece, trazer de volta cristãos afastados, reavivar a fé de quem está desacreditado. Em muitos momentos de suas mensagens televisionadas, o pastor dirige-se diretamente para a câmera com o dedo em riste, referindo-se ao telespectador:

"Deus está falando aqui agora, não sei o que é, pois ele nem sempre revela tudo. Agora é a tua oportunidade - para quem está me assistindo, essa é a hora de Deus para uma virada na tua vida, para tirar desse lugar baixo e te colocar num lugar 
alto" (Vitória em Cristo, 20 de abril de 2009, mensagem "Ensino especial para mudar a sua vida - parte 1").

"Deus tá respondendo a oração de quem veio aqui, de quem ligou nesse canal - Eu abro a porta agora - Esse é o dia da vitória!" (Vitória em Cristo, 22 de abril de 2009, mensagem "Ensino especial para mudar a sua vida - parte 3").

"Não sai da sala, pois Deus te plantou aí para ouvir isto! [sobre a prosperidade]" (DVD "Uma vida de prosperidade").

O fato de o pastor ser pentecostal explica em boa parte esse tipo de pregação, em que Deus falaria à audiência por meio do pastor; em que a ação divina poderia se cumprir durante o culto, tal como os dons do Espírito Santo manifestos nos cultos pentecostais - profecia, cura e glossolalia. Desses três, a profecia é mais comum nas pregações de Malafaia, em que profecias de vitória e prosperidade foram observadas de forma freqüente na amostragem analisada.

\section{Alcançando bem-estar e saúde}

$\mathrm{Na}$ publicação "Bíblia sagrada com orientações de saúde física, emocional e espiritual", encontramos a referência mais explícita sobre o sentido do bem-estar sob a ótica de Malafaia. A Bíblia, na tradução de João Ferreira de Almeida revista e corrigida, traz no final 112 páginas de orientações para conservar o bem-estar físico, emocional e espiritual. A saúde é considerada importante, pois os seres humanos são mordomos do corpo e da alma - "Deus conta conosco como crentes fisicamente saudáveis, emocionalmente equilibrados e espiritualmente fortalecidos” (Bíblia, 2006, p. 7). Não se trata de manter a saúde somente por sermos "templo do Espírito Santo", mas porque cada indivíduo foi criado para servir ao reino de Deus com suas plenas capacidades.

No que se referem à saúde física, as orientações versam sobre alimentação, higiene pessoal, prevenção de doenças, cuidados com o sono e com o descanso. Curiosamente, o interlocutor é feminino em boa parte dessas orientações. No que se refere à saúde emocional, o autor concebe que corpo, alma e espírito estariam interligados, o que tornaria a saúde emocional tão 
importante quanto a física: "aceite a saúde emocional como um direito seu e sua responsabilidade" (Bíblia, 2006, p.39). Ele orienta para que o leitor identifique e administre suas emoções, e evite o estresse por uma série de mecanismos de minimização de situações de pressão. Reforça a importância de evitar a cultura da competição e da pressa, reservando um tempo para ficar o leitor ficar a sós com Deus: "você é a sua prioridade; corte o que não for essencial, equilibre seu tempo" (Bíblia, 2006, p. 45). A valorização individual passa pelo cultivo da auto-estima e pela superação do complexo de inferioridade: "não confunda amor próprio com superioridade; máxime o seu potencial; viva consciente de sua identidade como filho de Deus. Você é príncipe, porque seu pai é o Rei da Glória (Romanos 8. 14; Mateus 6.9)" (Bíblia, 2006, p.64).

"Em toda a Bíblia, percebemos uma preocupação divina como bem-estar do homem nas áreas espiritual, emocional e física. Porém, há cristãos que espiritualizam tudo, e outros que 'psicologizam' tudo, o que também não é correto à luz das Escrituras. A salvação, segundo o que Deus planejou, deve trazer saúde integral: 'Amado, desejo que te vá bem em todas as coisas, e que tenham saúde, assim como bem vai à tua alma' (3 João 1.3)." (Bíblia, 2006, p.91).

Se o leitor vive momento de angústias profundas e tem tentado superar sozinho seus problemas, "saiba que não foi à toa que Deus colocou esta Bíblia com dicas de saúde em suas mãos. Ele fez isto porque o ama, deseja ser conhecido por você" (Bíblia, 2006, p. 91).

Muito anteriormente à psicologia e à psiquiatria, a Bíblia já revelara havia mais de cinco mil anos que a maioria das doenças emocionais seria causada por problemas espirituais. A palavra de Deus penetraria "onde Freud desejaria ter penetrado - na divisão da alma e do espírito, trazendo o que estava no mais profundo inconsciente, colocando-o na sua frente" (Bíblia, 2006, pp.89-91). Oração seria o maior tratamento psicoterápico do mundo, pois cura emocional é um processo que começa na verbalização ("Enfrentando problemas e seguindo em frente - parte 2", Vitória em Cristo, 31 de março de 2009). 
Deus usaria o "vaso limpo" para realizar sua obra na Terra, isto é, a santificação é um passo importante para alcançar saúde emocional e espiritual, por meio do jejum, da oração, da leitura, meditação e obediência à Bíblia, sujeitando-se ao Espírito Santo - "Deus pode usar o vaso pequeno, mas não o vaso sujo" (Bíblia, 2006, p. 103).

No vídeo "Vencendo a Depressão", o pastor demonstra que não rejeita o trabalho médico clínico, ao criticar pastores e cristãos que têm preconceito contra quem sofre de depressão, classificando-a como fraqueza de fé ou de caráter, influência satânica ou vida em pecado: "Se você está com problema físico, ou Jesus cura, ou procure um médico. Se você não se tratar, a doença fica crônica e pode te levar à morte. Vamos acabar com essa falsa espiritualidade!!" (Vitória em Cristo, 02 de maio de 2009, mensagem "Vencendo a depressão").

Dentro dessa perspectiva, a ideia central do ministério de Malafaia vitória em Cristo - surge como um objetivo a ser alcançado na vida cristã por meio de uma parceria entre o indivíduo e Deus. Da herança pentecostal, Malafaia traz a visão de batalha espiritual, em que o cristão é um soldado que luta contra o mundo. Porém, as críticas a uma suposta excessiva espiritualização de problemas humanos relativizam esse aspecto de batalha espiritual em sua pregação, chamando o indivíduo à responsabilidade por seus atos e por seu relacionamento com Deus. Assim, Malafaia centraliza sua produção na ideia de que o indivíduo cristão pode triunfar sobre seus problemas com a ajuda de Deus, por meio do estudo e da aplicação dos princípios bíblicos em sua vida, fortalecendo-se diante das adversidades.

\section{Parceira entre o indivíduo e Deus}

Ainda que Malafaia reforce em muitos produtos a necessidade de 0 cristão cultivar sua vida espiritual na igreja - seja ela qual for -, o alvo central de sua pregação é a vida individual, e como o indivíduo constrói um relacionamento próximo com Deus para obter suas vitórias. O conceito de vitória é bastante amplo nessa produção, pois Malafaia evita direcionar sua pregação para situações específicas; vitória pode significar tanto a superação 
de problemas físicos, emocionais, financeiros, como de relacionamento conjugal, educação de filhos, dentre outros. Essa concepção é aberta o suficiente para que o seu consumidor possa se identificar e inserir sua realidade no contexto da mensagem. Porém, o sentido dessa vitória é sempre delimitado no contexto de uma ética cristã que rejeita o consumismo, 0 hedonismo e o egoísmo.

A ideia de parceria pode ser entendida dentro da perspectiva desenvolvida por Zygmunt Bauman sobre religião pós-moderna, em que o fundamentalismo religioso permitiria um alívio da sobrecarga depositada sobre os indivíduos sobre o seu poder de escolha (1998). Contudo, observamos que o reforço na noção de parceria entre o ser humano e a divindade também se encaixa na lógica pós-moderna religiosa, pois ela atenua a solidão e a angústia da escolha, mas não elimina totalmente a participação individual na direção de sua vida:

"Aprenda a depender de Deus diariamente, entregando a Ele todas as suas necessidades e cuidados e crendo que Ele é fiel para dar a solução” (Bíblia, 2006, p.44).

“Creia que Deus está no controle de todas as coisas. Confie nele inteiramente. Permita que a paz divina proteja o seu coração contra a ansiedade” (Bíblia, 2006, p.48)

Deixamos de desfrutar os relacionamentos com entes queridos porque não aceitamos e/ou estamos ocupados demais com afazeres domésticos e profissionais "Sejamos pessoas orientadas pelo Espírito de Deus, que sabem que não são perfeitas (...) que confiam na promessa divina de que Aquele que em nós começou a boa obra, há de aperfeiçoá-la até o dia em que estaremos face a face com o Senhor (Filipenses 1:6)", (Bíblia, 2006, p.50).

A ideia de que Deus possui um plano para a vida do fiel não aparece tão forte e freqüente mas marca sua presença em alguns vídeos e nos livros "Como obter as respostas de Deus" e "Lições de Vencedor":

“O homem, às vezes, traça os seus planos, idealiza sua vida e não tem o cuidado de consultar o Senhor sobre suas decisões. Então, 
acaba se machucando. (...) aprenda a se submeter à vontade de Deus; deixe-o ser o Senhor de sua vida. (...) Não tema se a situação aparentemente for difícil; se o Senhor de fato o enviou, Ele levará a bom termo a sua jornada” (Malafaia, 2009, pp.43-44).

“A sua vida tem um propósito muito especial, porque Deus o criou não só para você ser uma benção na vida de outras pessoas, mas também para ser feliz e ter o nome dEle glorificado em sua vida. Portanto, não se anule como pessoa. Seja quem Deus propôs que você fosse, com a personalidade, os dons e os talentos que Ele o presenteou. Em todas as áreas (pessoal, familiar, profissional) assuma sua personalidade e faça a diferença no ambiente com sua maneira de falar, de agir e de comportar-se como uma pessoa autêntica, que á amada por Deus do jeito que é e com convicção da sua chamada cristã” (Bíblia, 2006, p. 52).

“Você é projeto de Deus!". Mesmo com as adversidades não se pode deixar ceder "nem perder o propósito e a nossa missão. Para isto é muito importante conhecermos bem a Deus e a missão que Ele designou para CAD um de nós. Peça ao Senhor que revele sua vocação, apresente-lhe seus projetos e ore diariamente para que Ele o ajude a realizá-los" (Bíblia, 2006, p.67).

Nessa parceria, Deus tem o poder de reverter circunstâncias desfavoráveis e de guiar para o melhor caminho, enquanto os homens possuiriam poder de escolha, enquanto Deus possuiria poder e autoridade para intervir conforme sua vontade. Assim, Deus estaria no controle do mundo espiritual (cita o exemplo do livro de Jó para mostrar que até Satanás agiria conforme os limites divinos), do mundo natural, da História e da vida de cada ser humano. Segundo o pastor, o crente não deveria se apavorar com crises econômicas, pois Deus proveria para cada necessidade humana - quando ele quer, manifesta sua vontade soberana. Trata-se de um argumento em que o indivíduo é retratado de forma apartada do seu contexto social e histórico, jamais uma vítima das circunstâncias, mas sim agente de seu destino com o auxílio divino.

Nesse vídeo, Malafaia exalta sua audiência a entregar o controle de suas vidas a Deus, conferindo um sentido aos sofrimentos e adversidades: "Você pode estar 
atravessando as piores lutas da sua vida - o mesmo Deus que permite que você passe por essas tribulações, adversidades, é esse mesmo Deus que tem pó der de mudar tua sorte e de resolver todo esse problema-Amém! Ele está no controle! [o profeta] Oséias entendeu isso! (...) Ele tem o poder para resolver qualquer parada!” (DVD “Deus está no controle").

Em outros produtos ele também ressalta a ideia de que o sofrimento é permitido por Deus para possibilitar um aprendizado no fiel. No programa Vitória em Cristo, as mensagens "Tempo de Conquistar", "Vencendo Batalhas", "Para você escolher o melhor”, "Quando vem a tribulação, o que fazer?”, "Enfrentando problemas $e$ seguindo em frente", "Vivendo triunfantemente" $e$ "Atitudes certas diante das adversidades" reforçam a noção de que as vitórias do cristão dão-se após lutas e adversidades - "nada se conquista com moleza" ("Vencendo as tentações"), e que os sofrimentos fazem parte desse processo. Porém, diferente de uma resignação diante dos eventos negativos, o pastor prega uma atitude mental positiva, visando o futuro em que "Deus tem uma coroa de vitórias para você" ("Um bom futuro para você"). As dificuldades podem ser uma confirmação de o fiel está no caminho certo, conforme o vídeo "Quer ser vencedor? Prepare-se para a oposição”.

Ao enfatizar que o sofrimento é natural na caminhada humana, e não motivo de fracasso pessoal, esse raciocínio reforça o argumento de trazer um alívio ao fardo da escolha (Bauman, 1998), em que o indivíduo seria o único responsável pelo seu destino. Conforme Daniela Bessa (2008, p. 205), a literatura de auto-ajuda cristã teria um efeito terapêutico positivo, pois ajudaria os evangélicos a lidar melhor com seus problemas pessoais:

"Cuidado com a mensagem errada de vida cristã [de que é tudo somente vitória]. Você é ser humano, tem direito de ficar triste, de chorar, de se lamentar, porque você precisa vivenciar as emoções negativas, até para ser curado delas" ("Enfrentando problemas e seguindo em frente").

O trecho a seguir sintetiza bem a noção de parceria, desenvolvida no ministério de Malafaia: "Seu sucesso dependerá de seu esforço, sua determinação e das 
oportunidades que Deus lhe conceder. Faça a sua parte, e Deus fará a dele" (Bíblia, 2006, p.83). O pastor garante que ninguém está sozinho com os seus problemas, e que é preciso aprender a entregar completamente essas tribulações nas mãos de Deus - "essa guerra é de Deus, ele cuida melhor que você". Outro argumento bastante comum nas pregações de Malafaia é o de que Deus não se moverá para fazer o que cabe ao ser humano, mas fará de tudo para ajudar naquilo que o ser humano não pode fazer ("Aquilo que você não pode fazer, certamente ele fará. Mas, o que é de sua responsabilidade, o Senhor não ria fazer por você" - Malafaia, 2009, p. 64). E, novamente, essas ideias podem se aplicar para qualquer situação difícil pelas quais os consumidores de sua mensagem possam estar passando, garantindo a abrangência da mensagem. Se por um lado Deus está no controle de tudo, ele também oferece a oportunidade de o indivíduo trilhar o seu caminho. O segredo do sucesso é saber trilhar o caminho sendo um "crente ativo na obra de Deus": "priorize os assuntos espirituais, diariamente leia e medite na Palavra de Deus, ore, seja assíduo frequentador dos cultos, oferte, contribua com o seu dizimo, evangelize, trabalhe na Seara do Mestre" (Malafaia, 2006, p.81).

Ainda que ele reforce esse aspecto de participar da igreja de Cristo como parte da santificação, a maior ênfase recai sobre como o fiel deve usar a capacidade humana para permitir que Deus faça a sua parte do processo de conquista de vitórias. No livro "Lições de Vencedor", encontramos um resumo mais esquematizado de ideias que estão presentes nos vídeos analisados:

Primeiro, ninguém recebe bênçãos se não sair da inércia: "Portanto, se você pensa que pode ficar parado, esperando que Deus faça tudo por você, está enganado. Lembre-se de que, no episódio da ressurreição de Lázaro, Jesus determinou que os homens tirassem a pedra que fechava o túmulo, e só então operou o milagre. Então, tire a pedra! Levante-se de onde está, escolha o melhor caminho ara receber o que deseja e vá em frente, com os olhos fitos no Senhor. Faça a sua parte” (Malafaia, 2009, p. 19).

Segundo, além de esforço, a ação humana também está subordinada à atitude mental do fiel: "aqui está o segundo ponto para aqueles que desejam ser otimistas: a maneira como pensamos acaba por determinar quem somos” (idem, p.22); “a maneira como você vê a vida vai determinar quem você é” (idem, p. 24). 
Terceiro, o sucesso depende do empenho da pessoa conforme a porta aberta por Deus. Malafaia critica os crentes desempregados que fazem muitas exigências para retornar ao mercado de trabalho. Trata-se de uma das poucas referências a problemas atuais que acometem os brasileiros. Porém, a atitude prescrita enfatiza a iniciativa individual, não importa o tipo de porta aberta por Deus: "Deus poderá abrir uma porta para você, mas e se for naquelas condições que você não gostaria? Pois mesmo que a oportunidade não pareça tão boa à primeira vista - quem sabe você terá que trabalhar durante as madrugadas, por exemplo -, saiba que essa é justamente aquela porta aberta que você tanto pediu ao Senhor. Esforce-se, esteja disposto a sacrifícios, sabendo que o Pai do céu tem bênçãos a operar em sua vida (...) Não se esqueça: a vitória vem mediante nosso esforço" (Malafaia, 2009, pp. 23-24).

Por fim, manter o foco na vitória futura, deslocando o olhar e a atenção excessiva do problema e do sofrimento no presente para a sua solução no futuro - " $a$ tribulação e a adversidade, com certeza, não durarão a vida toda. Se a situação agora está difícil, não desanime e não tenha medo - há um Deus com você! Ele é a sua vitória" (idem, p. 28).

Entretanto, não basta somente tomar essas iniciativas se a parte espiritual for negligenciada, visto que "há uma instância espiritual permeando todas as áreas de nossa vida" (idem, p.29). É necessário que o fiel seja um "crente ativo" - ou como o apóstolo Paulo, "pró-ativo" tanto nos assuntos práticos quanto nos espirituais.

O esforço pessoal é enfatizado no vídeo "Ensino especial para mudar sua vida", em que Malafaia apresenta à audiência do Congresso de Avivamento Despertai em Goiânia-GO o rapaz Alexandre, que veio da favela e pediu para trabalhar na igreja da Assembléia de Deus da Penha. Começou como faxineiro, e por empenho próprio conquistou posições dentro da igreja, até ser nomeado coordenador de eventos do ministério Vitória em Cristo. Nessa mensagem, ele conta também a história de três moças que foram alunas de Escola Dominical de sua esposa, Elizabeth Malafaia. Todas de origem humilde, durante a juventude esforçaram-se para conseguir uma boa formação profissional: na época da gravação da mensagem, uma delas era promotora de 
justiça do Rio de Janeiro, outra cursava medicina na UFRJ e a terceira era aviadora das Forças Armadas. Muitas vezes, posições humildes (em especial no campo profissional) são consideradas por Malafaia como a oportunidade dada por Deus para o fiel crescer se esse propósito se cumprirá é de responsabilidade do cristão.

\section{Os desvios no caminho para a Vitória em Cristo}

Tendo em mente os sentidos da noção de parceria entre Deus e o indivíduo no ministério de Malafaia, exploraremos de forma mais aprofundada os sentidos da noção de vitória, central para a pregação do pastor, permitindo uma grande abrangência de sua mensagem. Para isso, é importante analisar o que o pastor critica como conduta desviante, seja de crentes individuais, seja de igreja e da cultura evangélica com formação no Brasil. Dos quatro comunicadores analisados, Malafaia é o mais crítico das atitudes problemáticas na "igreja de Cristo" (no sentido amplo do conceito), que estariam impedindo que seus membros alcançassem vitórias e triunfos em suas vidas. Atitudes mentais derrotistas, excesso de ênfase em anjos e Satanás nos cultos, demasiado espaço dado para profecias e revelações, gosto pelo espetáculo e falta de profundidade bíblica estão dentre as acusações lançadas nas suas pregações, contribuindo para formar uma imagem de defensor da autoridade da igreja cristã por meio de uma pregação arrivista, agressiva, coloquial e satírica.

Conforme mencionado anteriormente, o público-alvo de Malafaia é o adulto evangélico. A aquisição de horários em uma emissora de rede nacional permite uma comunicação mais ampla, o que se traduziu na mudança do próprio visual de Malafaia e da identidade visual de seu programa. Ainda assim, ele não deixa de se referir a um ideal de cristão, seja por estar pregando para eventos evangélicos, seja por pregar em templos de diferentes igrejas evangélicas (em geral, pentecostais): “Um bom soldado procura sempre estar unido à tropa no campo de batalha. Se ele se mantiver isolado, estará vulnerável ao ataque do inimigo. Portanto, valorizemos sempre os cultos em nossa igreja” (Malafaia, 2006, p. 90).

Prevalece a representação do cristão combativo, cuja vida deve ser um testemunho positivo para a sociedade, e que não deve se dobrar às tentações do mundo e dos "modismos" da igreja. Por isso, juntamente com as lições para se alcançar a vitória 
segue-se uma grande quantidade de críticas de Malafaia quanto ao comportamento de evangélicos, sua conduta moral, conduta de pastores e práticas dentro de cultos.

Semelhante à ideia desenvolvida por Karen Armstrong sobre a religiosidade fundamentalista como guerreira e combativa, que cria uma contracultura não utópica para se contrapor à sociedade secular (2001, pp.9-17), encontramos em Malafaia a afirmação de que o cristianismo é "contracultura contra a cultura imposta pela sociedade", e que o cristão deve "fazer a diferença". Isso foi dito após uma crítica à falta de prática de princípios cristãos na vida de muitos crentes (perdoar, amar, dominar o seu eu, carregar a cruz). Acreditariam eles que a prática cristã é "dar glória a Deus mais alto", "gente que quer demonstrar que é mais santo que os outros" - "querem novidade? Ficam querendo fórmula mágica? (...) o que tem de crente atrás de lorota, de besteirol teológico,. Porque não tem profundidade com Deus; [vão] atrás de 'profetada' (sic), de 'visagem' (sic), e de 'revelamento' (sic) (...) cria vergonha nessa cara!” (DVD “As características de um verdadeiro cristão”).

$\mathrm{Na}$ mensagem "Ensino especial para sua vida", Malafaia também critica o "crente repelex", o fiel cuja vida é um mau testemunho perante a sociedade, além do "crente esquizofrênico", que é um santo na igreja, mas em casa é um horror. Com isso, critica políticos evangélicos que são corruptos (sem citar nomes), e reforça a ideia de que os cristãos são instrumentos de Deus para mudar seu ambiente e a vida ao seu redor. Em "Escolher o melhor", Malafaia critica o "crente avião", que pousa de igreja em igreja, sem estabelecer um compromisso com nenhuma comunidade; além de voltar-se contra os "supercríticos", que acreditam que nenhuma igreja é válida, procurando perfeição em tudo.

Já nos vídeos "Um bom futuro para você" e "As características de um verdadeiro cristão", critica veementemente a pirataria de artigos evangélicos e crentes que compram artigos pirateados, e crentes golpistas: "Agora, aqui, essa câmera [dirige-se diretamente para a câmera] o que tem de irmão com nome de crente [que é] trapaceiro, pilantra, moleque, passador de cheque sem fundo, descarado, sabe? (...)”. Reforça esse argumento para mostrar que em Cristo o ser humano deve ser renovado e, não, continuar cometendo os mesmo erros de antes da conversão. Esse e outros comportamentos são satirizados por Malafaia nas mensagens em vídeo, provocando 
risos nas audiências com as imitações de crentes adúlteros, golpistas, medrosos, entre outros.

Satiriza também a prática da "caixinha de promessas", denominada por ele de "cartomancia evangélica", e lança críticas contra o "crente gangorra", sem estabilidade emocional e espiritual para lidar com os problemas, pois ao invés de depositar a base de sua vida espiritual em Cristo, a deposita no pastor carismático ("se o pastor vai pra 'escandonga', tu vai também. Lamento que alguns pastores façam pose de superhomem, criando idolatria”); nas profecias e revelações da "irmã Doquinha" (ironizando a prática de revelações e profecias em geral a cargo de mulheres nas igrejas pentecostais), ou no cantor famoso (“As características de um verdadeiro cristão”). Em "Vivendo Triunfantemente", esbraveja contra pastores que estariam manipulando seus fiéis com profecias, bolas de fogo, anjos, línguas, fogo e poder, pois eles não estariam preparando os membros para lidar com as adversidades com estrutura espiritual e emocional: "Deixa de manipulação e prega a palavra!!".

Ele não deixa de demonstrar seu respeito por essas práticas nas igrejas, mas critica o espaço excessivo que elas teriam desfrutado nos cultos e na vida cotidiana dos fiéis, em detrimento da redução do tempo de pregação e do estudo bíblico. Um exemplo disso seria o grande destaque dado ao louvor e à adoração nos cultos e eventos evangélicos, para que a mocidade pudesse participar mais da vida na igreja, ou para "agradar a vaidade de quem canta e de quem ouve", sem que isso fosse acompanhado de uma base de estudo bíblico mais forte.

Dessa forma, Malafaia demarca sua posição como pastor e, portanto, defensor da autoridade oficial da igreja (no sentido amplo da noção de igreja de Cristo), apontando o que segundo ele seriam desvios cometidos pelas “ovelhas". E, além disso, ele procura delimitar um espaço de legitimidade frente à concorrência evangélica, mais notadamente as igrejas de Teologia da Prosperidade e as práticas de Confissão Positiva que circulam por entre igrejas pentecostais e não-pentecostais, conforme desenvolvemos na primeira seção desta pesquisa.

"Devemos acabar com esse negócio [de determinar a Deus o que ele deve fazer], irmãos. Deus fala do jeito que quer e da maneira que ele quer. Esse tipo de procedimento é idêntico à consulta no 
'escritório' da pitonisa ou ao sistema 0900. O cristão fica 'agoniado' e impaciente para ouvir a profecia, porque ele quer ouvir conforme o desejo de seu coração” (Malafaia, 2003, p. 27).

"De vez em quando, sobretudo nos dias de hoje, vemos muitos crentes que pretendem dizer a Deus o que ele deve fazer há até aqueles que desejam 'determinar' a ação do Todo-Poderoso. Quem age dessa forma está na contramão da Palavra, que é clara ao dizer que todo poder e toda a soberania pertencem ao Senhor" (Malafaia, 2009, p. 59).

"Não se iluda - o fato de crer em Jesus não é uma salvaguarda para o sofrimento. Os problemas são inerentes à condição humana. Nem sempre há compreensão a esse respeito. Muitos pregadores andam alardeando um evangelho em que não há espaço para as tribulações. É quase uma fé de super-homens, totalmente em desacordo com a realidade bíblica - afinal, o próprio Cristo era um homem de dores, que sabia exatamente o que é padecer" (Malafaia, 2009, p. 48).

O outro extremo desta atitude - o conformismo - também criticado por Malafaia, nas mensagens "Atitudes certas diante das adversidades" e "Tempo de Conquistar" - o cristão também deve ter ambições para melhorar de vida e querer se aperfeiçoar como crente: "Eu ando cheio! Por que tem gente que desiste e outros, não? É nossa incompetência! Por que tem tanto ímpio conquistando tudo e o povo de Deus não conquista nada? Porque não tem objetivo de vida!” (“Tempo de Conquistar”).

Outra crítica volta-se contra os crentes e igrejas que conferem grande poder a Satanás dentro da perspectiva de batalha espiritual, e aqueles que atribuem importância a anjos dentro de cultos, nas revelações e profecias. Na pregação de Malafaia não há tanto espaço para a figura de Satanás quanto na pregação de pastores neopentecostais que lhe fazem concorrência na TV.

O maior foco das pregações de Malafaia são os exemplos que podem ser retirados das ações de personagens bíblicos do Antigo e do Novo Testamento. Em geral, o objetivo central das mensagens televisionadas é tecer um comentário sobre uma 
determinada passagem bíblica (em geral curta, de poucos versículos), pontuada de sugestões de aplicação prática em situações do cotidiano. Dessa forma, a ênfase maior recai sobre como pessoas comuns são ajudadas por Deus e/ou por Cristo para lidar com situações difíceis. Para reforçar esses argumentos, Malafaia por vezes cita experiências próprias de como Deus o ajuda em momentos cruciais, mas dificilmente menciona experiências de outras pessoas, ou insere relatos de outros fiéis. A sua palavra é a que prevalece como testemunho e como autoridade baseada no estudo bíblico - na "hermenêutica bíblica", como ele costuma mencionar em vídeos e livros, a fim de citar passagens dentro do seu devido contexto.

Apesar da formação de psicólogo de Malafaia, o que prevalece é a sua visão de pastor; não se encontra nas produções do pastor carioca nenhuma semelhança com o trabalho do psicólogo Augusto Cury, que transforma Jesus em Mestre dos Mestres, com um exemplo de vida e de administração emocional a ser imitado. Seguindo a tradição da mensagem da morte redentora de Cristo, o Jesus de Malafaia é o filho de Deus que desceu à Terra com uma missão redentora da humanidade. Em Malafaia, a figura de Cristo é mais lembrada no convite à entrega da vida a Cristo feito ao final de boa parte dos programas de TV; nas mensagens, vemos uma profusão de citações bíblicas para ilustrar lições de diferentes personagens, ressaltando o caráter de parceria entre Deus e seus filhos na conquista da vitória.

\section{Trilhando o caminho para a Vitória em Cristo}

No início de algumas mensagens em vídeo, transmitidas pela televisão e disponíveis em DVD, tal como um animador de auditório, Malafaia comanda "uma palavra profética" a ser proferida pela audiência para quem ele discursará: "Vitória em Cristo para sua vida!", seguida de uma salva de palmas. São vários os sentidos para essa vitória propagada por Malafaia, que se tornou o foco central de seu ministério.

Não basta somente ser cristão, mas agir como cristão e assumir uma atitude mental e emocional que deveria ser condizente com a condição de cristão. Conforme observamos nas críticas feitas aos "desvios" cometidos por evangélicos, somente um tipo de cristão pode ser de fato vitorioso: 
"Você quer ser vitorioso? Ter uma vida abençoada $e$ abençoadora? Então faça a escolha certa. Dê o primeiro passo em direção ao Senhor. Ele quer mudar a sua história, endireitar as suas veredas e lhe dar a vitória. Mas para isso você precisa entregar a sua vida a Jesus (...) Agindo assim, você entrará para o grupo das pessoas que temem ao Senhor e que desfrutam dos benefícios de Sua eterna aliança” (Bíblia, 2006, pp. 94-95).

No livro "Lições de Vencedor" ele afirma que somente o fato de o cristão ter aceito Jesus Cristo como Senhor e Salvador já um primeiro passo para a vitória, pois Cristo derrotou a morte e o mal, e quem está com ele não deve temer a destruição. Para reforçar isso, conta um episódio em que ele próprio chegou à quase exaustão depois de ter tentado exorcizar uma casta de demônios de um rapaz por mais de sete horas. Por fim, o que determinou sua vitória foi o fato de ter evocado a Cristo decisivamente:

“(...) só me lembro de uma palavra que disse quando o endemoninhado partiu para cima de mim, como um animal que vai abocanhar a pesa. Com autoridade, eu falei: 'Se você passar por cima de quem está comigo, você me mata.' Já viu bola de gás de aniversário quando perde o barbante e ela vai esvaziando? No instante em que eu disse isso, aconteceu exatamente assim. Então o demônio falou, abaixando a mão: 'Eu não posso fazer nada contra você, porque quem está com você me derrotou no Calvário"”" (Malafaia, 2009, p. 111).

Essa é a única referência encontrada em toda amostragem relativa a Malafaia de referência explícita à batalha espiritual. Em 2007 ele lançou a Bíblia com orientações para Batalha Espiritual e Vitória Financeira, mas o foco central da maioria de suas produções tem sido a vitória em Cristo em um sentido mais amplo.

Outro sentido desenvolvido em livros e mensagens de vídeo tem sido a vitória contra o "mundo", mais explicitamente apresentada no livro "O Perigo da Inversão de Valores", com o intuito de demonstrar os desvios dentro da comunidade evangélica a fim de abrir os caminhos para a atitude correta que levaria a uma vida vitoriosa: valorização maior de bens materiais do que de pessoas; de aparência em detrimento de virtudes; de serviço cristão ao invés da família; dos dons e das experiências espirituais 
do que da Palavra de Deus; da comunhão com os ímpios do que com os irmãos em Cristo; dos interesses pessoais do que dos interesses do Reino de Deus; de outros lugares do que da igreja; dos talentos do que do caráter; da autoridade própria do que a autoridade divina; dos boatos da internet do que do testemunho da vida cristã.

"Muitas vezes, Deus quer revelar-lhe algo especial que vai abençoá-lo mas você nem se dá conta disso, porque ainda está com a mente escravizada por filosofias e pensamentos mundanos, pois, em vez de ler a Palavra de Deus e pensar nas coisas que são do alto (Colossenses 3. 2), você fica horas em frente à TV assimilando as ideologias disseminadas pelas novelas e outros programas que ridicularizam os valores cristãos" (Bíblia, 2006, pp. 106-107).

Dessa forma, a vitória não é para qualquer cristão: "Querido leitor, fundamentado na Palavra de Deus, eu declaro que Deus tem um profundo interesse em sua vida. Ele dispõe de inúmeras respostas para lhe dar, respostas para todos os pedidos que você lhe tem feito durante os seus momentos de intimidade com ele. Saiba que ele o acompanha durante todo o seu dia, e conhece o seu levantar e o seu deitar. (...) A vitória é para aqueles que se submetem ao senhorio de Jesus, que não se apegam às coisas materiais e sim que procuram viver de acordo com o que Deus propõe na sua Palavra" (Malafaia, 2003, p.64).

Ao abordar a vitória de Davi sobre Golias, no vídeo "Vencendo Batalhas", Malafaia afirma que o sentido da vitória do cristão sobre seus problemas é o de prestar um testemunho para não-crentes sobre a grandeza do Deus único; para alicerçar a fé dos irmãos; e para que outros, evangélicos e não evangélicos, acreditem que eles também podem vencer. Por mais difícil e complexo que seja o problema, há sempre a possibilidade de vencê-lo com a ajuda de Deus e com o esforço individual, com todas as limitações e com os melhores talentos, pois não somente Satanás não possui legalidade espiritual para destruir o homem, como o ser humano foi criado por Deus para ser vitorioso. Bastaria a pessoa se conscientizar disso e permitir que Deus mostrasse a ele o caminho, segundo Malafaia. 
A atitude do fiel é fundamental, ao passo que Malafaia profetiza e declara as promessas de Deus de vitória, afirmando que o importante não são as derrotas e as perdas na vida, mas o fiel saber a hora de mudar, de tomar uma atitude para alcançar a sua superação: "Deus te trouxe aqui porque ele quer te dar uma receita - não tem derrota que vai me parar! Declare que você acredita em nome de Jesus [em coro com a audiência] Eu tenho promessas de Deus que vão se cumprir! Eu vou chegar à vitória! Glória a Deus!!” (“Ensino especial para mudar a sua vida”). Nesse trecho do DVD, ao final da mensagem, ele declara as promessas de Deus para uma platéia que responde entusiasticamente à sua pregação cada vez mais exaltada, com gritos de glória a Deus e aleluia, braços erguidos e mãos espalmadas; a câmera focaliza pessoas chorando e louvando, conferindo emoção à pregação.

Um passo importante para obter vitórias na vida é ter ambição e sonhos, além de estabelecer metas. De uma forma muito semelhante a de Augusto Cury, cujo Best-seller "Nunca desista de seus sonhos" figura em listas de livros mais vendidos seculares e evangélicos, Malafaia ressalta a importância de se ter objetivos na vida e se acreditar em sonhos. Se o sonho for algo legítimo, conferido por Deus para o coração do fiel, basta que ele persevere para que o sonho seja concretizado - tal como ele fez, no caso do seu ministério de comunicação, conforme citado anteriormente. A ambição serviria para manter o foco do fiel na busca por uma melhora contínua de sua vida.

No que se refere a conquistas materiais, no vídeo "Tempo de Conquistar", Malafaia critica os cristãos que não possuem ambições e objetivos na vida, e preferem viver com a sua "porção acostumada": “Trouxa! (...) quer dizer que tu não quer comer picanha maturada, quer comer carne de terceira todo dia? Problema seu! Eu quero ter a ambição de conquistar porque essa Terra ele [Deus] deu aos filhos dos homens" (“Tempo de Conquistar").

Quando o fiel se dispõe a conquistar sua vitória, deve se preparar para a oposição, que virá não somente da sociedade, mas em especial das pessoas mais próximas. Cita seu próprio exemplo, de que recebe duras críticas dos próprios irmãos em Cristo por conta do programa, e em especial por conta do tempo que despende em cada programa para pedir doações. A oposição é a confirmação de que o fiel está fazendo o melhor para Deus, incomodando as trevas. Por sua vez, o sofrimento faz parte deste processo para melhor preparar a pessoa para o que será conquistado: 
"Na trajetória da vida, você também, com certeza, terá de enfrentar muitos empecilhos, mas jamais desanime. Quando estiver se sentindo massacrado, derrotado e tudo estiver ruim ao seu lado, quando parecer que ninguém está se importando com você, com a sua vida e seus problemas, fique firme. Você está começando a trilhar o caminho para a vitória! E quando você pensar que lhe sobrevirá o pior fracasso de sua vida, Deus usará aquela aparente derrota para lhe dar a maior vitória” (Malafaia, 2009, p. 69).

Durante a caminhada rumo à vitória (sobre o que exatamente, ele não menciona, mas fica subentendido que são os problemas pelos quais o leitor está passando), o fiel não pode se sentir infeliz pelas circunstâncias desfavoráveis ou pela prosperidade de outros. Diferente de técnicas de obras como "O Segredo", em que se prega a visualização do objetivo desejado e um estilo de vida em que o leitor age como se já tivesse obtido o seu objetivo, Malafaia prega uma conduta mais realista:

"Uma coisa é o que é meu. Outra, o que é do próximo. Uma coisa é o que Deus abençoa; outra, é aquilo que ele quer me dar. (...) Viva de acordo com as circunstâncias que Deus lhe concedeu. Aprenda a viver no Evangelho com fartura ou em apertos sem deixar de ser feliz. Querer viver uma vida acima de nosso padrão só nos trará problemas." (Malafaia, 2009, p. 82).

Vários problemas podem se interpor entre o fiel e sua vitória: Satanás, o pecado, as lutas da vida e as tribulações. Mas Deus nunca o abandonará, pois ele conhece todas as necessidades de seus filhos e não deixará que nada acabe com sua vida. $O$ triunfalismo de Malafaia é intenso em boa parte de suas pregações, tal como vem ocorrendo em boa parte da cultura evangélica nos últimos anos (Cunha, 2004):

"Não sei qual é o seu problema, a sua necessidade, ou aquilo que o está perturbando. Todavia, o apóstolo Paulo concluiu dizendo: 'Mas em todas estas coisas somos mais do que vencedores, por aquele que nos amou' (Romanos 8:37). (...) A Bíblia diz: 'Se Deus é por nós, quem será contra nós?' Declare isso! Sua luta é momentânea; a 
vitória está diante de você, em algum lugar do futuro. Pode ser daqui a um segundo, amanhã, ou no mês que vem. O tempo não importa. $O$ que tem importância é que a sua vitória já está assegurada!” (Malafaia, 2009, p. 102).

A vitória como testemunho é também uma forma de Deus usar o fiel para ajudar a outras pessoas a serem vitoriosas, pois é importante que se lembre que outros passam por problemas muito maiores do que o do fiel. A vitória deve ser compartilhada sempre:

"Há quem se torne mesquinho depois de conquistar a benção. A primeira coisa que faz é sonegar o dízimo. A seguir, quando já está insensível, perde completamente a vergonha, e como ninguém sabe quanto ganha, acaba dando ao Senhor apenas cinco por cento, ou três por cento - isso quando dão alguma coisa! Além disso, tornam-se insensíveis diante da necessidade dos outros. Mas o Senhor não abençoa ninguém para que se torne egoísta, e sim, para que seja benção para muitos!” (Malafaia, 2009, p. 74).

Uma ideia que deveria estar no horizonte do fiel que almeja à vitória - em especial aquela que envolve conquistas materiais e financeiras - é a noção de que a vida humana está composta pela esfera material e espiritual. Com isso, ele critica as "igrejas que só pregam a Teologia da Prosperidade”, pois isso seria perigoso; e critica também as igrejas em que "é tudo espiritual", pois o mundo não teria nada para quem é cristão. Ele estabelece uma diferença entre mundo e Terra - o "mundo" de fato não teria nada para os cristãos, mas a Terra foi dada aos seres humanos. Por isso, é importante que o fiel almeje conquistar vitória no campo espiritual e material igualmente ("Tempo de Conquistar").

"Para ser vitorioso, eu tenho que obedecer a palavra de Deus, trabalhar, me esforçar, sonhar, deixar para trás o que é ruim, não desistir mesmo que tenha chovido derrotas, e ter Jesus como Senhor da sua vida (...) É Jesus que completa e satisfaz; sem ele você vai ser rico, mas você vai para o Inferno, sem ter vida eterna (...) [toda 
riqueza material] sem Jesus, rico não dava tiro na cabeça nem tomava remédio para dormir" ("Vivendo Triunfantemente").

Para Malafaia, é imprescindível que o fiel entenda o mecanismo pelo qual Deus confere prosperidade aos homens. Ele lança mão de um argumento bastante conhecido no cristianismo: a prosperidade é diferente da mera riqueza, pois a primeira pressupõe uma aliança com Deus para gerir as riquezas que ele oferece ao fiel; a prosperidade pressupõe a riqueza abençoada com a paz interior e a alegria que somente um fiel submisso a Deus poderia alcançar. Dessa forma, a riqueza seria ressignificada no imaginário cristão, despida de cobiça, egoísmo ou individualismo (DVD, "Uma vida de Prosperidade").

Entretanto, no vídeo "Uma Vida de Prosperidade", Malafaia não se prende tanto no sentido de prosperidade e, sim, no caminho para se obtê-la. A "receita de Deus" é a "lei da liberalidade", cujo entendimento estaria sendo "neutralizado por Satanás" para deixar os cristãos no caminho do engano. Conforme explorado no início desta seção, a liberalidade refere-se aos dízimos e ofertas que o evangélico despende na igreja e nas obras referentes ao "Reino de Deus" (ministérios, obras sociais, etc). Dos quatro comunicadores analisados, Malafaia é o que explicitamente aborda a prosperidade, e, coincidência ou não, dos comunicadores analisados é o que mais depende diretamente de doações e ofertas para manter seu ministério no Brasil.

Para o pastor, oferta é "firme fundamento de glória", dentro da lógica de que Deus retribui a quem doa. Para que as ofertas retornem em abundância para os fiéis que doam, elas devem ser um ato planejado, feito de coração e de vontade própria: " $o$ cristão é conhecido pelo que dá e, não, pelo que recebe; não pelos dons, mas pelos frutos". Se o fiel entender o sentido da oferta e da maneira correta de fazê-la, quatro leis espirituais agirão a seu favor: primeiro, a lei da semeadura, em que só se colhe o que se planta e na proporção do que foi plantado, sendo que cada semente (oferta) tem o seu tempo de maturação (não adianta ofertar hoje para receber de volta amanhã). Segundo, quem oferta tem provisão na área material e espiritual. Terceiro, a lei da multiplicação da oferta dada; e quarto, a lei da abundância -Deus retribui em abundância para que o beneficiado ajude a outros.

\footnotetext{
${ }^{7}$ Um dado curioso sobre esse vídeo: quando a pesquisadora adquiriu esse e outros produtos no estande da Editora Central Gospel na VI Expo Cristã, em 2006 (17 de setembro de 2006), ouviu do vendedor que o pastor Silas Malafaia fez todos os funcionários da Editora assistirem a mensagem.
} 
Para o pastor, a oferta é um ato tão espiritual quanto o louvor, a oração, e a distribuição de folhetos (evangelização). A adoração é o oferecimento de uma dádiva em reconhecimento à soberania e à misericórdia divina: “como nos atrevemos a não dar nada?". A oferta é uma semente a ser plantada com paciência, "adubada" com amor cristão, expectativa, fé e confiança na ação de Deus. Para ilustrar seus argumentos, ele fecha a mensagem com quatro casos ocorridos com ele, após ele ter feito uma doação de toda sua humilde poupança a um pastor em dificuldades, quando tinha 14 anos.

Relata que em vários momentos do seu ministério e de sua vida pessoal encontrou-se em dificuldades, foi à bancarrota seis vezes, mas sua fidelidade sempre foi recompensada, ainda que não urgentemente. Por fim, ele chama ao púlpito pessoas que estão desempregadas e lhes dá entre dez e vinte reais, para que eles façam uma oferta em suas igrejas, aplicando os princípios ensinados: "Deus quer mudar a história de crentes, de cidades; creia na Bíblia, e não, no sistema econômico!’.

Em "Lições de Vencedor", como pontuado anteriormente, Malafaia reforça a importância da lei da liberalidade como chave para a prosperidade e para a vitória. $\mathrm{Na}$ carta aos filipenses, o apóstolo Paulo falava a uma igreja fiel, dizimista, que contribuía com liberalidade para a obra de Deus, e por isso recebia em abundância. Mas o ser humano é falho, e por isso Deus sempre abre a possibilidade para renovar seu pacto com os indivíduos:

"Por isso, antes de mais nada, renove seu pacto de fidelidade para com Deus. Se você é fiel, ótimo. Porém, se sabe que tem falhado, não deixe de renová-lo hoje mesmo! Não importa sua igreja, a denominação a que pertence; se você quer ser abençoado, faça um pacto de fidelidade com Deus, prometendo ser fiel em seu dízimo e em suas ofertas (...) agora que você fez um, novo pacto com Deus, saiba que a única possibilidade de ele ser quebrado é por sua culpa, porque Deus é eternamente fiel! Ele é a provisão para todas as necessidades!” (Malafaia , 2009, p. 114).

Qual a diferença entre a "lei da liberalidade", que não aparece nominalmente dessa forma na Bíblia, e a Teologia da Prosperidade surgida em meados do século XX, 
e que vem ao Brasil a partir dos anos 1960 e 1970? Aparentemente, nenhuma, por mais que Malafaia insista na sua diferenciação. Em ambos os casos, trabalha-se com a lógica de que o dinheiro doado pelo fiel reverterá em bênçãos materiais e/ou espirituais, pressupondo uma ligação indissociável entre e esfera material e a espiritual (Campos, 1997).

Nesse último trecho transcrito acima, os termos da parceria determinam que o fiel faça a sua parte, o que significa ofertar com liberalidade, sob o risco de não ver a sua vitória acontecer. Prática esta que ressoa outras práticas religiosas brasileiras, dentro do catolicismo e das religiões afros, em que se trabalha com a ideia de ofertar às deidades (santos, orixás) a fim de obter benefícios na Terra. O fato de Malafaia atacar a Teologia da Prosperidade não significa que ele se distancia totalmente dela, mas sim que deseja legitimar sua prática, desqualificando a dos concorrentes.

\section{Conclusão}

O que viria a ser esta cultura do bem-estar que pastores como Silas Malafaia estariam ajudando a fomentar nos últimos anos no cenário evangélico? Algumas mensagens cristãs disponíveis no mercado evangélico procuram oferecer uma noção de bem viver no mundo sem ceder ao hedonismo ou ao individualismo secular, ao mesmo tempo em que abrem, como em um "arminianismo pós-moderno", a possibilidade de os indivíduos buscarem a salvação dos pecados da pobreza, da falta de iniciativa, da infelicidade e da derrota, aqui e agora na terra.

Nesta concepção de bem-estar emocional, qualquer pessoa poderá adaptar suas aflições aos problemas mais amplos detectados, buscando soluções individualizadas, com o auxílio de Deus. Um cuidado de si que aparta o sujeito de suas relações mais imediatas e de uma compreensão ampla do contexto social em que se insere. Pelo prisma da concepção do plano de Deus para alcançar a vitória, garante-se algo que muitos não conseguem acertar em suas vidas - um rumo definido -, por meio de um triunfo sobre o que afligir fiel. A vitória, portanto, nunca é definida em termos absolutos, sobre dificuldades específicas, o que dá ensejo ao consumidor inserir e identificar sua própria batalha e seus próprios inimigos, recrutando Deus para lhe conferir vitória certa. O que vale para Malafaia é a vontade do fiel em se engajar na vida cristã; é a escolha que ele realiza. São as suas atitudes e o quanto consegue resistir aos 
perigos do mundo. O bem-estar e o sucesso estão nas mãos do fiel, enquanto Deus oferece as condições para ele conquistá-las.

A visão de mundo de Malafaia é arrivista, contemplando uma grande quantidade de inimigos e tentações plantados por Satanás para acabar com os cristãos. A missão de Malafaia é alertar sobre isso, sobre os falsos profetas e heresias, sobre os perigos da inversão de valores, que torna "normal" o que é demoníaco. Para ele, o ser humano é frágil e suscetível aos ardis da TV, da internet, da propaganda e da moda. É a velha leitura do que os meios de comunicação são poderosos diante de uma audiência passiva, ainda muito comum, diante de uma sociedade com histórico de concentração de meios de comunicação nas mãos de poucos grupos e empresários. Porém, essa crítica é feita por alguém que há 30 anos fez da comunicação o seu ministério, e que tem usado este meio para expressar suas opiniões, seus ensinamentos, seus apoios e desafetos políticos e religiosos. Portanto, suas críticas aos propagadores de valores mundanos também são críticas a concorrentes seculares e religiosos no plano comunicacional e cultural.

Para além destas batalhas, a chave do sucesso individual está na parceria entre Deus e o ser humano. A única certeza propagada é a de que Deus tem um plano e uma vitória reservados a quem o buscar. Estaria esta noção de bem-estar de fato trazendo o conforto que apregoa, se pensarmos que o fracasso se reputaria às más escolhas do indivíduo, não deixando Deus fazer sua parte no processo de vitória e superação pessoal? Que dizer da angústia que a lei da liberalidade pode gerar naquele que tem seus parcos recursos investidos num propósito divino? Ao apostar em uma religiosidade de ações e decisões imediatas para alcançar os mais diversos resultados, tal caminho para o bem-estar é repleto de ambivalências, em que a urgência dos problemas humanos recebem um tratamento passo-a-passo, sujeito à ação e à súplica individual, e ao ritmo e à intervenção divinos, acionáveis e, ao mesmo tempo, imperscrutáveis.

\section{Referenciais}

BÍBLIA sagrada com orientações de saúde física, emocional e espiritual. Rio de Janeiro: Editora Central Gospel,2006.

MALAFAIA, Silas. Uma vida de prosperidade. DVD. Rio de Janeiro: Editora Central Gospel, col.,50min., c.2000s.

As características de um verdadeiro cristão. DVD. Rio de Janeiro: Editora Central Gospel, col., 80min., c.2000s.

col.,50min., c.2000s.

Deus está no controle. DVD. Rio de Janeiro: Editora Central Gospel, Programa Vitória em Cristo. Band TV. Rede Nacional.col., 60 min., 
05h00-06h00. Produção: Associação Vitória em Cristo - Rio de Janeiro-RJ.

Programas gravados nos dias:

05 de março de 2009 - "Um bom futuro para você" - parte 1

06 de março de 2009 - "Um bom futuro para você" - parte 2

26 de março de 2009 - "Tempo de Conquistar"

31 de março de 2009 - "Enfrentando problemas e seguindo em frente"

06 de abril de 2009 - "Vivendo Triunfantemente"

07 de abril de 2009 - "Atitudes certas diante das adversidades" - parte 1

08 de abril de 2009 - "Atitudes certas diante das adversidades" - parte 2

09 de abril de 2009 - "Vencendo Batalhas" - parte 1

12 de abril de 2009 - "Para você escolher o melhor"

13 de abril de 2009 - "Vencendo Batalhas" - parte 3

14 de abril de 2009 - "Quanto vem a tribulação, o que fazer?" - parte 1

15 de abril de 2009 - "Quanto vem a tribulação, o que fazer?" - parte 2

20 de abril de 2009 - "Ensinamento que vai transformar sua vida" - parte 1

22 de abril de 2009 - "Ensinamento que vai transformar sua vida" - parte 3

28 de abril de 2009 - "Vencendo as tentações" - parte 1

29 de abril de 2009 - "Vencendo as tentações" - parte 2

30 de abril de 2009 - "Vencendo as tentações" - parte 3

02 de maio de 2009 - "Vencendo a depressão"

MALAFAIA, Silas. Lições de Vencedor. São Paulo: Thomas Nelson Brasil, 2009.

Central Gospel, 2004.

.Atenção!!! Você e sua família estão em perigo. Rio de Janeiro: Editora

Gospel, 2006.

.O perigo da inversão de valores. Rio de Janeiro: Editora Central

Gospel, 2003.

Como obter as respostas de Deus. Rio de Janeiro: Editora Central

BAUMAN, Zygmunt. O Mal-Estar da Pós-Modernidade. Rio de Janeiro: Jorge Zahar Editor, 1998.

BELLOTTI, K.K. Joyce Meyer: bem-estar espiritual e emocional na mídia evangélica. Revista Brasileira de História das Religiões, v. ano 4, p. 117-148, 2011.

Viva o hoje: $\mathrm{O}$ bem-estar evangélico na obra de Max Lucado

sob um olhar cultural. Rever (PUCSP), v. 12, p. 31-65, 2012.

BESSA, Daniela Borja. Literatura de auto-ajuda cristã: em busca da felicidade ainda na terra e não só para o céu. Tese de Doutorado em Ciências da Religião, PUC-SP, 2008.

GIDDENS, Anthony. As consequências da modernidade. São Paulo: EdUnesp, 1991. JENKINS, Henry. Convergence Culture - where old and new media collide. New York, London: New York University Press, 2006.

Recebido:25/09/2012

Received: 09/25/2012

Aprovado: 28/11/2012

Approved: 11/28/2012 